\title{
Erratum to: Ruptured sinus of Valsalva aneurysm association with bicuspid aortic valve
}

\author{
G. Ertaș • A. S. Çetinkaya • M. E. Memetoğlu
}

(C) Springer Media / Bohn Stafleu van Loghum 2012

Erratum to: Neth Heart J (2012)

DOI 10.1007/s12471-011-0148-7

The correct spelling of the 3rd authors name is Memetoğlu.

The online version of the original article can be found at http://dx.doi.org/ 10.1007/s12471-011-0148-7.

G. Ertaș $(\bowtie) \cdot$ A. S. Çetinkaya

Department of Cardiology, Gümüşhane Government Hospital,

Daltaban Semti Hasan Bey District,

29000 Gümüșhane, Turkey

e-mail: drgokhanertas@yahoo.com.tr

M. E. Memetoğlu

Department of Cardiovascular Surgery,

Gümüşhane Government Hospital,

Gümüşhane, Turkey 